\title{
Komplikasi Autonomic Dysreflexia Pasca Cedera Medula Spinalis
}

\author{
Dimas Rahmatisa*), Iwan Fuadi“*), Sudadi ${ }^{* * *}$ ) \\ ${ }^{*}$ Departemen Anestesiologi Rumah Sakit Pusat Otak Nasional, "*)Departemen Anestesiologi dan Terapi Intensif \\ Fakultas Kedokteran Universitas Padjadjaran-RSUP Dr. Hasan Sadikin Bandung, ${ }^{* * *}$ Departemen Anestesiologi \\ dan Terapi Intensif Fakultas Kedokteran Universitas Gadjah Mada-RSUP Dr. Sardjito Yogyakarta
}

\begin{abstract}
Abstrak
Cedera medula spinalis merupakan kejadian yang sering dijumpai di Amerika Serikat, dengan biaya perawatan kesehatan seumur hidup yang tinggi berdasarkan tingkat kecacatan fungsional. Permasalahan yang timbul dapat berupa masalah psikologis, fisik, dan sosial, yang dapat menghabiskan biaya yang sangat besar. Tatalaksana kasus cedera medula spinalis terus menjadi tantangan pada tiap fase perawatan, mulai dari awal terjadinya cedera, hingga perawatan dan pemulihan pasca tindakan operasi, karena angka masuk ulang ke rumah sakit pasca perawatan tetap tinggi. Salah satu komplikasi cedera medula spinalis adalah adanya perubahan sistem saraf autonom dapat terjadi akibat kerusakan pada kontrol simpatis sehingga menyebabkan komplikasi yang dikenal sebagai autonomic dysreflexia (AD), yang muncul selama fase pemulihan. Manifestasinya dapat berupa hipertensi berat dengan bradikardia paradoks, kemerahan kulit, dan sakit kepala, penyakit ini dapat menyebabkan kecacatan jangka panjang dan gangguan kardiovaskular. Terapi untuk pasien dengan AD umumnya bertujuan untuk pemulihan gejala dengan cepat hal ini sangat penting karena karena dapat terjadi komplikasi parah yang mengancam jiwa bila gejala yang ada tidak ditangani dengan segera. Pencegahan yang tepat, pengenalan dini, dan manajemen akut adalah faktor penting dalam tatalaksana AD.
\end{abstract}

Kata kunci: disrefleksia autonom; cedera medula spinalis; hipertensi

JNI 2019; 8 (3): 207-16

\section{Autonomic Dyreflexia Complication after Spinal Cord Injury}

\begin{abstract}
Spinal cord injury is a common occurrence in the United States, with high lifetime health care costs based on the level of functional disability. Problems that arise can be psychological, physical, and social problems, which can cost a lot of money. Management of spinal cord injuries continues to be a challenge in each phase of treatment, from the beginning of the injury, to treatment and recovery after surgery, because the rate of re-entry to the posttreatment hospital remains high. One complication of spinal cord injury is the presence of autonomic nervous system changes that can occur due to damage to sympathetic control resulting in complications known as autonomic dysreflexia (AD), which appears during the recovery phase. The manifestation can be life-threatening hypertension with paradoxical bradycardia, flushing, and headache, this disease can cause further long-term disability and cardiovascular disorders. Therapy for patients with AD generally aims to recover symptoms quickly this is very important because because there can be severe life-threatening complications if the symptoms are not treated immediately. Proper prevention, early recognition, and acute management are important factors in the maangement of AD.
\end{abstract}

Key words: autonomic dysreflexia; spinal cord injury; hypertension

JNI 2019; 8 (3): 207-16 


\section{Pendahuluan}

Cedera medula spinalis merupakan kejadian yang sering terjadi. Di Amerika Serikat, insidens dari cedera medula spinalis sekitar 52 kasus per 1 juta orang per tahun, dengan sekitar 17.500 kasus baru cedera medula spinalis setiap tahunnya. Prevalensi dari kasus cedera non-traumatik tidak diketahui secara pasti, namun prevalensi cedera medula spinalis traumatik pada tahun 2017 di Amerika Serikat sekitar 285.000 orang. ${ }^{1}$ Permasalahan yang timbul dapat berupa masalah psikologis, fisik, dan sosial, yang dapat berjumlah sangat besar. Estimasi biaya yang dikeluarkan untuk menangani kasus cedera medula spinalis dari awal sampai akhir, dapat mencapai 1-3 juta dolar Amerika Serikat. ${ }^{2,3}$

Tatalaksana kasus cedera medula spinalis terus menjadi tantangan pada tiap fase perawatan, mulai dari awal terjadinya cedera, sampai fase perawatan dan pemulihan pasca tindakan operasi, karena angka masuk ulang ke rumah sakit pasca perawatan tetap tinggi, bahkan hingga 20 tahun ke depan. Cedera medula spinalis biasanya berhubungan dengan kasus paralisis, dan pada kasus gagal napas berhubungan dengan ketergantungan terhadap mesin ventilator. Gangguan seksual, yang kadang terjadi bersamaan dengan kehilangan kontrol pada usus dan kandung kemih, dapat menimbulkan gangguan emosional, psikologis, dan juga fisik..$^{2,4}$

Perubahan sistem saraf autonom dapat terjadi akibat kerusakan pada kontrol simpatis, dan bahkan gejala tersebut lebih membuat pasien merasa tidak nyaman dibandingkan kondisi paralisis dan disabilitas pasca terjadinya cedera. Pada fase akut, gejala yang timbul bervariasi, mulai dari hipotensi ortostatik, sampai yang berat yaitu bradikardia dan vasodilatasi perifer. Pada fase subakut sampai dengan fase kronik, gejala yang timbul dapat menjadi terbalik, yaitu hipertensi akut yang dapat mengancam nyawa. Gejala ini disebut Autonomic dysreflexia (AD), yang merupakan mekanisme kompensasi yang muncul selama fase pemulihan. ${ }^{2,5}$ Paparan kronik terhadap hipertensi yang berat ini akan mengakibatkan kerukan endotel vaskular, sehingga dapat menyebabkan kenaikan risiko untuk terjadinya penyakit kardiovaskular sebesar 3 hingga 4 kali lipat, pada pasien dengan cedera servikal atau torakal tinggi. Timbulnya kelelahan dan latihan yang tidak dilakukan dengan baik akan menghambat pemulihan. ${ }^{5}$ Tingkat keparahan AD dapat berupa hipertensi asimtomatik, hingga berupa krisis hipertensi, perdarahan intrakranial, dan bahkan henti jantung, sehingga membutuhkan pengenalan gejala klinis yang tepat dan hati-hati. Serangan ini bisa memperpanjang masa rawat di rumah sakit sehingga perlu menjadi perhatian serius. ${ }^{2,6}$

\section{Patofisiologi}

Pada fase akut, pasca cedera medula spinalis servikal atau torakal tinggi, terjadi penurunan aktivitas dari saraf simpatis. Hal ini ditunjukan oleh pemeriksaan katekolamin yang rendah pada darah, dan metabolit urinnya, dan juga ditunjang dengan pemeriksaan klinis yaitu hipotensi.2 Krum et al menunjukkan bahwa dibandingkan dengan kontrol, pasien yang mengalami AD akan didapati tekanan darah yang signifikan lebih rendah, selaras dengan kadar norepinefrin yang juga lebih rendah dengan kadar klirens yang sama antara 2 kelompok. ${ }^{7}$

Lebih lanjut pula, telah ditunjukan adanya enzim dopamin hidroksilase dengan kadar yang normal menuju rendah pada pasien pasca cedera medula spinalis. Enzim tersebut berfungsi untuk mengubah dopamin menjadi norepinefrin, sehingga kadar norepinefrin akan menurun. ${ }^{2}$

Sistem pengaturan saraf pada AD tetap intak, namunpadaADterjadirefleks spinalautonomyang tidak terkoordinasi akibat adanya cedera medula spinalis diatas segmen T6 yang mengganggu kontrol dari neuron simpatis preganglionik pada medula spinalis di torakolumbal. Jika terjadi distensi dari usus atau kandung kemih, refleks simpatis keluar dibawah level dari cedera medula spinalis, yang akan berakibat vasokonstriksi dan hipertensi. Kemudian refleks yang diinduksi oleh baroreseptor, akan menyebabkan bradikardia dan vasodilatasi diatas level dari cedera medula spinalis yang dimediasi oleh sistem parasimpatis, yang akan menyebabkan gejala kemerahan dan 
nyeri kepala. ${ }^{8}$ Gejala hipertensi pada pasien AD muncul sebagai respons dari beberapa faktor, yang mempengaruhi sistem persarafan. Kontrol tonus simpatis berada pada ventrolateral neuron medula dan neuron preganglionik simpatis pada intermediolateral pada medula spinalis di daerah torakolumbal. Akson-akson dari neuron preganglionik simpatis keluar melalui medula spinalis dari arah ventral, dan kemudian bersinaps pada rantai paravertebral atau ganglia pravertebral, dan berakhir pada post ganglionik organ target, kelenjar, dan piloerektor. ${ }^{9}$

Cedera medula spinalis pada segmen servikal dan torakal tinggi dapat mengganggu kontrol tonus tersebut. Dengan perjalanan waktu, terjadi peningkatan level dari nerve-growth factor (NGF) yang menyebabkan pengeluaran calcitonin gene-related peptide (CGRP + ) pada aferen serabut simpatis ke dalam medula spinalis, yang akan membentuk sirkuit baru intraspinal yang tidak di regulasi oleh kontrol tonus simpatis yang dilakukan oleh medula. ${ }^{10}$ Sirkuit baru ini dipercaya menjadi faktor kunci dalam transmisi dan propagasi dari sinyal disrefleksia. Kemunculan dari neuron preganglionik simpatis jalur aferen berhubungan dengan derajat cedera yang dialami. Cedera yang menyebabkan kejadian $\mathrm{AD}$ adalah cedera yang berat, bukan cedera ringan, atau kompresi medula spinalis biasa. Penelitian-penelitian saat ini sedang

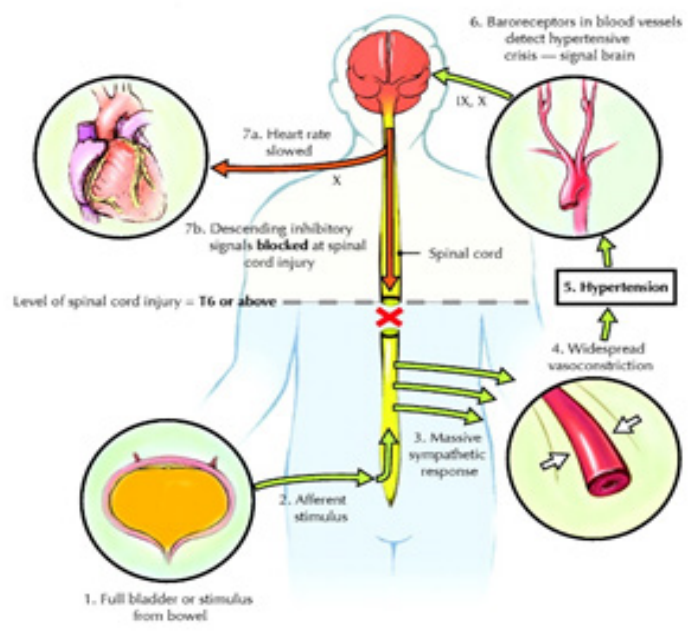

Gambar 1. Patofisiologi autonomic dysreflexia

Dikutip dari: Krenz N. and Weaver $\mathrm{L}^{10}$ dilakukan untuk mengetahui jalur kimiawi yang terlibat, sehingga mampu memperkecil risiko terjadinya $\mathrm{AD} .{ }^{2}$ Secara anatomi, $\mathrm{AD}$ telah dilihat bahwa cedera medula spinalis mempengaruhi tonus simpatis diatas level T6 yang membuat seseorang memiliki predisposisi mengalami $\mathrm{AD}$, walaupun ada beberapa laporan bahwa $\mathrm{AD}$ dapat juga terjadi pada level bawah, yaitu T10. Terdapat juga korelasi antara keparahan dari gejala $\mathrm{AD}$ dengan ketinggian level dari cedera medula spinalisnya. Semakin tinggi level cedera, maka gangguan autonom yang terjadi pun akan semakin besar dan hebat. ${ }^{8}$ Perubahan morfologi pasca cedera akan mempengaruhi fungsi neuron simpatis. Setelah terjadinya cedera, akson dari neuron simpatis preganglionik akan mengalami atrofi yang kemudian akan dengan berjalannya waktu secara bertahap kembali ke morfologi normal. Atrofi yang terjadi pada fase awal ini. ${ }^{10}$

Atrofi yang terjadi pada awal, kemungkinan merupakan gambaran awal dari kehilangan tonus simpatis, dengan adanya gangguan dari kontrol neuronal medula yang terjadi pasca cedera medula spinalis level tinggi. Kondisi morfologi yang kembali normal seiring berjalannya waktu namun tetap mengalami kehilangan kontrol tonus dari neuron ventromedular akan menyebabkan terjadinya respons hipertensi pada stimulus aferen, seperti yang dapat terlihat pada pasien yang mengalami $\mathrm{AD} .^{2}$ Selain dari perubahan pengaturan pada sistem saraf pusat, respons yang berlebihan juga terlihat pada perifer melalui alfaadrenoreseptor, yang diduga sebagai penyebab lain dari gejala munculnya tonus simpatis yang berlebihan ini. Penelitian yang dilakukan pada hewan dan manusia telah menunjukan terjadi peningkatan sensitivitas dari reseptor norepinefrin setelah terjadinya cedera medula spinalis.

Penelitian pada roden juga menunjukan adanya peningkatan respons yang berlebihan arteri mesenterika terhadap fenilefrin., ${ }^{2}$ Penelitian yang membandingkan pasien quadriplegia dengan kontrol, setelah menerima infus vasopressor yang identik, terdapat peningkatan kadar katekolamin yang sama ditemukan pada kedua kelompok, meskipun respons terhadap vasopressor tersebut sangat berbeda. ${ }^{2}$ 


\section{Gejala Klinis}

Ciri-ciri yang khas pada pasien dengan $A D$ termasuk hipertensi yang mengancam jiwa dengan kulit memerah, sakit kepala, dan mual yang mirip dengan serangan hipertensi urgensi dan hipertensi emergensi. Kondisi hipertensi disebabkan oleh vasokonstriksi yang dimediasi tonus simpatis sebagai respons terhadap rangsangan nyeri maupun tidak nyeri (atau tidak beracun), terbatas pada pembuluh darah di bawah tingkat cedera medula spinalis. Vasokonstriksi ini menyebabkan krisis hipertensi. Peningkatan tekanan darah sistolik bisa setinggi $300 \mathrm{mmHg}$, dan dapat terjadi hingga $41 \mathrm{x} /$ hari (rata-rata $11 \mathrm{x} /$ hari) pada mayoritas pasien-pasien yang mengalami cedera medula spinalis di atas level T5. ${ }^{13}$ Sebaliknya, pembuluh darah di atas level cedera medula spinalis mengalami vasodilatasi sehingga akan menyebabkan gejala berupa kemerahan, mual, dan muntah. Vasodilatasi yang terjadi diperantarai oleh sistem parasimpatis yang lebih dominan. Bradikardia juga sering terlihat, dan juga berhubungan dengan saraf parasimpatis. ${ }^{13}$ Stimulus yang paling sering menyebabkan terjadinya $\mathrm{AD}$ adalah distensi pada usus dan atau kandung kemih, selain itu berbagai stimulus lain adalah pemasangan foley kateter, dan bahkan mengencangkan tali sepatu juga pernah dilaporkan dapat memicu AD. ${ }^{2}$

Tingkat keparahan dari AD mungkin tidak secara spesifik berhubungan dengan derajat stimulasi aferen, namun cedera medula spinalis yang komplit memiliki angka kejadian AD 3 kali lipat lebih besar dibanding yang inkomplit. Komplikasi abdomen pada $\mathrm{AD}$ mencapai $10 \%$ dari kematian setelah cedera medula spinalis dengan risiko tertinggi pada beberapa bulan pertama setelah cedera. Mual sering dikaitkan dengan AD, sekunder akibat tonus vagal yang dimediasi saraf parasimpatis di atas level cedera medula spinalis. Komplikasi sekunder akibat $\mathrm{AD}$ merupakan cedera yang disebabkan oleh hipertensi, termasuk diantaranya disfungsi penglihatan, nefropati, pankreatitis, dislipidemia, kolesistitis, dan hepatopati. Kerusakan sistem ini harus dipantau secara ketat dan ditata laksana secara tepat dan cepat. Identifikasi dan eliminasi rangsangan yang menstimulus terjadinya $\mathrm{AD}$ harus dilakukan dalam manajemen $\mathrm{AD} .^{2}$ Dekompresi usus dan kandung kemih harus dilakukan, dan investigasi adanya obstruksi pada sistem tersebut juga harus dilakukan. Menggunakan pakaian yang ketat, termasuk diantaranya manset tekanan darah otomatis harus dihentikan, sampai kita benarbenar tahu faktor stimulus apa yang mencetuskan AD pada pasien. ${ }^{2}$

\section{Perubahan pada Autonomic Dysreflexia}

Sejumlah komplikasi sistemik telah dikaitkan dengan $\mathrm{AD}$, sering sebagai komplikasi hipertensi kronik yang berat.

\section{Perubahan Kardiovaskular}

Hipertensi berat dapat menyebabkan peningkatan tekanan intrakranial, kejang, dan perdarahan intrakranial. Komplikasi kardiovaskular termasuk diantaranya berupa iskemia miokard, aritmia, dan edema paru. Manifestasi klinis termasuk Peningkatan tekanan darah minimal $20 \%$, kemerahan, nyeri kepala, berkeringat, piloereksi, sumbatan hidung dan lain lain. ${ }^{14}$

Tabel 1. Berbagai Stimulus yang dapat Memicu Terjadinya Autonomic Dysreflexia

\begin{tabular}{llll}
\hline Gastrointestinal & Genitourinari & Muskuloskeletal & Kulit \\
\hline Konstipasi & $\begin{array}{l}\text { Distensi vesika } \\
\text { urinaria }\end{array}$ & Spasme otot & Ulkus penekanan \\
Ileus & $\begin{array}{l}\text { Infeksi saluran } \\
\text { kemih }\end{array}$ & Nyeri & Laserasi \\
Kram & & Spastisitas & $\begin{array}{l}\text { Manset tekanan } \\
\text { darah otomatis }\end{array}$ \\
& & & Pakaian ketat \\
\hline
\end{tabular}

Dikutip dari: Kottapaly $\mathrm{M}^{2}$ 
Pasien dengan lesi servikal yang tinggi sering memiliki hipersensitivitas vagal yang menyebabkan bradiaritmia. Kondisi ini biasanya bersifat sementara, dengan sebagian besar kasus sembuh dalam jangka waktu 5 minggu dari cedera, meskipun kadang-kadang ada kasus yang membutuhkan intervensi lebih lanjut, seperti pemasangan alat pacu jantung. ${ }^{14}$ Pasien AD juga berisiko terkena penyakit kardiovaskular karena kekurangan aktivitas fisik, massa otot berkurang, dan perkembangan sindrom metabolik termasuk diabetes. Risiko kardiovaskular penyakit meningkat dengan bertambahnya usia, dan juga dengan semakin tinggi dan lesi medula spinalis yang lebih parah. Sekitar 40\% kematian pada pasien dengan cedera medula spinalis kronik disebabkan penyakit kardiovaskular.13

\section{Perubahan Muskuloskeletal}

Penurunan aktivitas otot yang terjadi mendadak pasca terjadinya cedera medula spinalis akut akan menyebabkan perubahan cukup besar pada muskuloskeletal. Hilangnya beban mekanis akan mengakibatkan kehilangan tulang dan atrofi otot. Hilangnya massa otot di bawah level cedera telah dilaporkan sebesar $15-50 \%$ selama tahuntahun pertama. Hal Ini menyebabkan penurunan laju metabolisme karena kehilangan otot dan peningkatan penyimpanan lemak jika asupan tidak disesuaikan dengan pengeluaran. Osteoporosis pada tulang bisa terjadi setelah cedera medula spinalis. Standar emas untuk mendiagnosis osteoporosis pada populasi berbadan sehat adalah pemindaian dual-energy $x$-ray absorptiometry (DXA). Namun, kriteria yang digunakan untuk menentukan keberadaan osteoporosis pada populasi tersebut mungkin tidak berlaku untuk populasi cedera tulang belakang, karena osifikasi heterotopik $(\mathrm{OH})$ dan perubahan neuropatik dapat mempengaruhi hasil pemindaian DXA. ${ }^{2}$ Fraktur ekstremitas bawah adalah rangsangan penting untuk $\mathrm{AD}$ dan kehilangan tulang ekstremitas bawah menempatkan individu pada peningkatan risiko. Osifikasi heterotopik adalah pengendapan tulang yang abnormal di jaringan lunak di bawah level cedera medula spinalis, terutama di ekstremitas bawah dan sekitar sendi pinggul. Hal ini dapat menyebabkan aktivasi AD
karenaHOdapatmenjadistimulus yangberbahaya. ${ }^{2}$

\section{Aliran Darah Otak}

Individu yang mengalami episode $\mathrm{AD}$ terpapar pada fluktuasi besar tekanan darah setiap hari karena fluktuasi antara hiperaktif otonom dan hipotensi ortostatik. Gejala hipotensi ortostatik ini membantu menurunkan tekanan darah pada episode tekanan darah yang meningkat. Tekanan darah sistolik dapat naik hingga 300 mmHg selama episode parah $\mathrm{AD}$, dengan gejala susunan saraf pusat seperti kebingungan, stroke, dan perdarahan. Investigasi aliran darah serebral menggunakan Dopler transkranial dengan pemantauan tekanan darah non-invasif secara simultan, yang dilakukan selama episode spontan $\mathrm{AD}$, menunjukkan bahwa autoregulasi serebrovaskularmengalamiperubahan. Kegagalan autoregulasi dapat menyebabkan individu cenderung mengalami perdarahan intrakranial dan komplikasi susunan saraf pusat lainnya. ${ }^{2}$ Studi aliran darah ini menunjukkan bahwa autoregulasi serebrovaskular tampaknya utuh selama episode hipertensi spontan tetapi ada autoregulasi yang buruk selama periode tekanan darah rendah yang menyebabkan penurunan aliran darah dan perfusi otak dan meningkatkan risiko komplikasi SSP termasuk stroke., ${ }^{2,14}$

\section{Disfungsi Sistem Imun}

Kekurangan kekebalan sekunder akan menyebabkan peningkatan risiko infeksi yang terjadi setelah cedera akut pada otak dan medula spinalis. Hal ini mungkin terkait dengan persarafan simpatis dari aksis hipofisishipotalamus-adrenal. Aktivasi neuron simpatis pada tulang belakang menyebabkan pelepasan glukokortikoid dan norepinefrin dan mendukung fungsi kekebalan tubuh pada kondisi tubuh yang normal. Namun, aktivasi simpatis yang tidak terkontrol dapat menyebabkan pelepasan glukokortikoid dan norepinefrin yang abnormal, yang dapat menurunkan fungsi kekebalan tubuh. Hipotesis ini diuji dalam model eksperimental cedera medula spinalis dan AD kronis, yang menunjukkan pelepasan katekolamin yang signifikan dan penurunan fungsi kekebalan. ${ }^{2}$ Pencegahan atau pengobatan AD yang lebih baik 
dapat meningkatkan kesehatan kekebalan tubuh pada individu setelah cedera medula spinalis dan mengurangi morbiditas dan mortalitas jangka panjang. ${ }^{2}$

\section{Gangguan Psikologis}

Rasa sakit dan kecemasan merupakan keluhan yang umum terjadi pasca cedera medula spinalis dan secara dramatis dapat mempengaruhi kualitas hidup seseorang. Gejala-gejala ini kadang-kadang dapat secara langsung atau tidak langsung terkait dengan episode AD., ${ }^{2,14}$ Autonomic dysreflexia setelah cedera medula spinalis mengganggu kualitas hidup karena gangguan kemampuan untuk melakukan aktivitas hidup sehari-hari dan meningkatkan risiko cedera seperti jatuh dari kursi roda. Selain itu, penarikan akut dari obat antispasmodik seperti baclofen bisa menyakitkan dan kadang-kadang mengancam jiwa. ${ }^{2}$ Penarikan mendadak dari baclofen yang diberikan secara intratekal akibat tidak berfungsinya pompa baclofen yang diimplantasikan dapat menyebabkan kecemasan yang signifikan pada populasi ini. Pengobatan AD bersama dengan pengobatan nyeri neuropatik, kecemasan, dan depresi dengan obat-obatan seperti pregabalin dapat meningkatkan kualitas hidup pada individuindividu ini. ${ }^{2}$

\section{Komplikasi Kulit}

Ulkus akibat penekanan adalah salah satu komplikasi paling umum pada individu setelah cedera medula spinalis, dengan angka dilaporkan setinggi $30 \%$ dalam beberapa penelitian barubaru ini. Banyak dari pasien ini memerlukan rekonstruksi bedah luka mereka, dan $\mathrm{AD}$ dapat secara signifikan mempengaruhi manajemen perioperatif., ${ }^{2,14}$ Autonomic dysreflexia dapat meningkatkan kejadian terbukanya kembali luka yangmenutup dan pembentukanhematomasetelah pembedahan rekonstruksi untuk ulkus dekubitus. Strategi intraoperatif seperti menggunakan anestesi spinal dan nitrat intraoperatif dan agonis opiat untuk menumpulkan respon simpatik memiliki beberapa manfaat. Osifikasi heterotopik dan spastisitas juga dapat mempersulit pemulihan pasca operasi. Selain itu, hipertensi ortostatik dapat menyebabkan hipoperfusi jaringan dan penyembuhan luka yang buruk setelah operasi. Sebaliknya, kelenturan dapat memicu terjadinya terbukanya kembali luka dan nekrosis flap. Karena itu, sangat penting untuk waspada terhadap gejala-gejala ini dan mengobatinya dengan cepat. ${ }^{2}$ Melakukan tatalaksana nyeri yang baik pascaoperasi bertujuan untuk menghindarkan pasien dari stimulus yang berpotensi berbahaya walaupun pada beberapa pasien yang tidak mengeluhkan nyeri pascaoperatif karena cedera neurologis mereka, mereka masih mungkin terkena AD dari stimulus nosiseptif. ${ }^{2}$

\section{Terapi Autonomic Dysreflexia}

Biaya rata-rata perawatan rumah sakit untuk AD cukup besar, apalagi bila sampai terjadi pemanjangan waktu rawat inap, hal ini menunjukan pentingnya terapi pencegahan dan perawatan tepat waktu dari komplikasi yang mahal ini. Pada penelitian, model eksperimental AD telah mengidentifikasi beberapa mekanisme yang berpotensi penting untuk menjadi target terapi, termasuk peradangan, saraf yang menyimpang dengan serat $\mathrm{CGRP}+$, dan peningkatan kadar NGF tulang belakang. Namun, sebagian besar investigasi ini belum maju ke studi yang lebih jauh lagi, akibatnya, belum ada terapi medis yang berguna yang berlaku untuk mengobati individu yang hidup dengan $\mathrm{AD}{ }^{2}$ Terapi untuk pasien dengan $\mathrm{AD}$ umumnya bertujuan untuk pemulihan gejala dengan cepat hal ini sangat penting karena karena dapat terjadi komplikasi parah yang mengancam jiwa seperti stroke, kejang, dan infark miokard, bila gejala yang ada tidak ditangani dengan segera. ${ }^{2}$ Robekan pembuluh darah dapat terjadi akibat fluktuasi tekanan darah yang ekstrim.. Angka mortalitas bisa mencapai $22 \%$ pada pasien yang terkena komplikasi perdarahan intrakranial. Edema paru neurogenik juga dapat terjadi, yang biasanya diakibatkan oleh aktivitas simpatis yang tidak diimbangi parasimpatis di dalam pembuluh darah paru, yang kemudian dapat menyebabkan kegagalan pernapasan. ${ }^{2}$

Hal yang menarik, adalah bahwa terdapat banyak pasien yang mengalami episode AD tanpa memberikan gejala dan respon fisiologis 
Tabel 2. Efek sistemik Autonomic Dysreflexia

\begin{tabular}{|c|c|c|c|c|c|c|c|}
\hline $\begin{array}{l}\text { Muskulo } \\
\text { skeletal }\end{array}$ & $\begin{array}{l}\text { Kardio } \\
\text { vaskular }\end{array}$ & Neurologi & $\begin{array}{l}\text { Genito } \\
\text { urinari }\end{array}$ & $\begin{array}{l}\text { Psiki- } \\
\text { atrik }\end{array}$ & Sistem Imun & Endokrin & Mata \\
\hline $\begin{array}{l}\text { Osteopo- } \\
\text { rosis }\end{array}$ & $\begin{array}{l}\text { Hiper- } \\
\text { eaktivitas } \\
\text { autonom }\end{array}$ & $\begin{array}{l}\text { Perdarahan } \\
\text { oak }\end{array}$ & $\begin{array}{l}\text { Nefropati } \\
\text { hipertensif }\end{array}$ & Ansietas & $\begin{array}{l}\text { Defisiensi } \\
\text { imun } \\
\text { sekunder }\end{array}$ & Pankreatitis & $\begin{array}{l}\text { Neuropati } \\
\text { hipertensi }\end{array}$ \\
\hline Atrofi otot & $\begin{array}{l}\text { Hipotensi } \\
\text { ortostatik }\end{array}$ & $\begin{array}{l}\text { Stroke iske- } \\
\text { mik } \\
\text { Perubahan } \\
\text { autoregu- } \\
\text { lasi serebral }\end{array}$ & & Depresi & $\begin{array}{l}\text { Pressure } \\
\text { ulcer }\end{array}$ & Kolesistitis & $\begin{array}{l}\text { Neuropati } \\
\text { optik }\end{array}$ \\
\hline $\begin{array}{l}\text { Osifikasi } \\
\text { heterotopik }\end{array}$ & & Kejang & & & $\begin{array}{l}\text { Penyem- } \\
\text { buhan luka } \\
\text { tidak baik }\end{array}$ & Dislipidemia & \\
\hline $\begin{array}{l}\text { Deposisi } \\
\text { lemak }\end{array}$ & & & & & & & \\
\hline
\end{tabular}

Dikutip dari: Kottapaly $\mathrm{M}^{2}$

yang abnormal tidak dapat diprediksi. Hal ini terlihat ketika dilakukan pemantauan jantung selama pemeriksaan urodinamik untuk mengetahui disfungsi saluran kemih neurogenik. Ini menggarisbawahi pentingnya pemantauan jantung yang cermat selama prosedur yang diketahui memicu ketidak stabilan autonom. ${ }^{2}$

\section{Terapi Medis}

Dua mekanisme yang mendasarai untuk AD adalah munculnya serat $\mathrm{C}$ nosiseptif abnormal di segmen tulang belakang di bawah tingkat cedera dan disfungsi neurotransmisi glutamat yang berkontribusi terhadap inisiasi visero-simpatis spinal yang menyebabkan episode hipertensi. Akibatnya, ada minat dalam pengujian kegunaan dari farmakoterapi seperti gabapentin yang menghambat pelepasan glutamat presinaptik. ${ }^{2}$
Pada model eksperimen, pengobatan dengan gabapentin setelah terjadi cedera komplit pada medula spinalis, menunjukan adanya perbaikan dari spastisitas, namun tidak mengubah variabel hemodinamik ataupun mencegah episode $\mathrm{AD}{ }^{2}$ Penatalaksanaan serangan akut AD melibatkan stabilisasi hemodinamik serta penghilangan agen atau stimulan yang berbahaya. Koreksi tekanan darah yang cepat dapat dicapai dengan obat-obatan yang beraksi pendek dan cepat. Nitrat adalah terapi akut yang paling umum digunakan karena efek relaksasi langsung pada otot polos pembuluh darah.2 Penggunaan nitrat, harus dihindari pada pasien yang memakai sildenafil untuk pengobatan disfungsi ereksi, karena interaksi antara kedua obat ini dapat menyebabkan hipotensi yang mengancam jiwa. Pengobatan akut dengan

Tabel 3. Beberapa Target Terapi yang Umum diberikan pada Pasien AD

\begin{tabular}{llll}
\hline Nyeri & Hipertensi & Inkontinensia Urin & Spastisitas \\
\hline Gabapentin & Nitrat & Kateter urin & Baclofen \\
Pregabalin & Beta bloker & Intravesika botulinum & Tizanidin \\
& Penghambat & Intrasfingter botulinum & Botulinum \\
& kanal kalsium & & \\
& \multicolumn{2}{c}{ Prazo- } & \\
& sin & & \\
\hline
\end{tabular}

Dikutip dari: Kottapaly $\mathrm{M}^{2}$ 
anti hipertensi oral seperti nifedipin sering mengakibatkan hipotensi dan efek samping seperti pusing, kelelahan, dan kelemahan. Nifedipin bekerja pada sistem renin angiotensin dan reseptor alfa adrenergik. Terapi antihipertensi kerja cepat dan onset pendek lainnya seperti hidralazin dan labetalol juga sering dilakukan. ${ }^{2}$ Ada bukti eksperimental bahwa hipertensi akut yang dialami selama AD mungkin terkait dengan peningkatan ekspresi reseptor adrenergik alfa1 perifer setelah cedera medula spinalis. Hal ini menyebabkan peningkatan respons fenilefrin dari bagian arteri femoral in vitro, serta peningkatan respons hipertensi terhadap fenilefrin dalam vivo. Prazosin adalah alfa adrenergik bloker selektif dan dapat secara langsung mengatasi perubahan fisiologis ini dan menghasilkan efek samping hipotensi yang kurang dalam penggunaan klinis karena tidak memengaruhi sistem renin angiotensin. ${ }^{2}$ Tizanidine adalah turunan imidazol dan agonis alfa-2 adrenergik yang bekerja secara terpusat yang mengurangi eksitasi pelepasan asam amino dalam neuron intraspinal.

Efek saping obat ini termasuk kelelahan dan mengantuk, pusing, kelemahan otot, halusinasi, dan insomnia, dan umumnya terkait dosis dan dengan demikian titrasi digunakan untuk meminimalkan efek ini. ${ }^{2}$ Baklofen adalah obat pilihan untuk spastisitas yang disebabkan oleh cedera medula spinalis. Baklofen berikatan dengan reseptor GABA (B) dalam sumsum tulang belakang, yang mengarah ke hiperpolarisasi membran dan penurunan masuknya kalsium ke terminal presinaptik, mengurangi pelepasan neurotransmitter rangsang. Baklofen dapat diberikan secara oral dan cepat diserap tetapi tidak memiliki efek samping sistemik yang signifikan termasuk sedasi dan hipotensi. Perawatan jangka panjang kadang-kadang diberikan melalui pompa dan kateter implan, yang mengantarkan obat langsung ke cairan tulang belakang, memungkinkan konsentrasi yang lebih tinggi pada dosis yang lebih rendah. Seperti yang disebutkan sebelumnya, penghentian baklofen intratekal yang tiba-tiba dapat menyebabkan gangguan yang mengancam jiwa yang disebut sebagai intrathecal baclofen withdrawal syndrome. Kondisi ini dapat menyebabkan spastisitas yang ekstrim, hipertermia maligna, kejang, dan $\mathrm{AD} .^{2}$

Dalam sebagian besar kasus, ada episode AD yang disebabkan faktor genitourinari. Selain itu, gejala AD pada pasien setelah SCI biasanya berlangsung lama dan memerlukan manajemen jangka panjang pada sebagian besar pasien. Toksin botulinum A bekerja dengan cara menghambat pelepasan asetilkolin presinaptik di persimpangan neuromuskuler dan menciptakan keadaan denervasi fungsional, yang menghilangkan stimulus yang meningkat karena spastisitas kandung kemih. Suntikan botulinum toksin intravesikular disetujui oleh Food and Drug Administration (FDA) pada tahun 2011 untuk pengobatan inkontinensia yang terkait dengan kandung kemih neurogenik. Selanjutnya, terapi ini telah digunakan untuk episode-episode $\mathrm{AD}$ yang tidak dapat diterima dengan pendekatan-pendekatan khas untuk menghilangkan rangsangan dan mengendalikan hipertensi dengan obat-obatan. ${ }^{2}$ Suntikan botulinum toksin A intravesikular dan intrasfingter telah bermanfaat untuk memperbaiki gejala yang terkait dengan AD pada anakanak dengan aktivitas detrusor neurogenik yang berlebihan yang terkait dengan $\mathrm{AD} .^{2}$

\section{Terapi Akan Datang}

Di masa depan, obat regeneratif dapat meningkatkan kesempatan untuk meningkatkan fungsi kardiovaskular setelah cedera medula spinalis. Model eksperimental transplantasi sel induk (stem cell) menunjukkan harapan untuk meningkatkan perubahan hemodinamik setelah transeksi medula spinalis. Secara khusus, transplantasi sel-sel induk saraf yang diturunkan dari batang otak meningkatkan ketinggian abnormal dalam tekanan arteri ratarata yang terlihat dengan $\mathrm{AD}$ yang diinduksi setelah transeksi medula spinalis. Selain itu, ada peningkatan hipotensi pada awal (istirahat) tetapi tidak pada bradikardia istirahat abnormal. Efek-efek ini terlihat dengan sel-sel induk saraf yang diturunkan dari batang otak, tetapi tidak berasal dari sumsum tulang belakang. Ini mungkin karena kemampuan mereka untuk mengembalikan persarafan serotonergik dan adrenergik di bawah tingkat cedera. ${ }^{2}$ 


\section{Manajemen Intraoperatif Autonomic Dysreflexia}

Manajemen AD intraoperatif terdiri dari terapi farmakologis dan terapi non farmakologis. Terapi non farmakologis yaitu ${ }^{15}$ :menghilangkan semua stimulus yang dapat mencetuskan $\mathrm{AD}$, termasuk hentikan sementara tindakan operasi, dekompresi organ yang distensi, misal kandung kemih, usus, atau jika menggunakan laparoskopi, harus dilepaskan terlebih dahulu, posisikan head-up agar mencetuskan hipotensi ortostatik

Terapi Farmakologis yaitu ${ }^{15}$ : dalamkan anestesia, bisa dengan memberikan bolus dari propofol, atau membuka gas inhalasi lebih besar, naikkan fraksi oksigen sampai kondisinya teratasi, terapi aritmia dengan menggunakan obat beta bloker atau antikolinergik, berikan antihipertensi onset cepat seperti nikardipin atau nitrogliserin

\section{Simpulan}

Autonomic dysreflexia adalah komplikasi umum cedera medula spinlis kronis. Kondisi ini bisa mengancam jiwa dan berdampak besar pada kualitas hidup. Pencegahan, pengenalan dini, dan perawatan dini adalah yang terpenting. Di masa depan, sejumlah terapi medis baru mungkin tersedia untuk individu yang hidup dengan AD. Selain itu, kemajuan dalam bidang terapi sel induk dapat memberikan peluang penyembuhan

\section{Daftar Pustaka}

1. National Spinal Cord Injury Statistical Center. Facts and Figures at Glance. Birmingham, AL: University of Alabama at Birmingham; 2015. Diunduh dari: https://msktc.org/lib/docs/Data_Sheets_/ SCIMS Facts and Figures 2017 August FINAL.p.pdf. Diakses tanggal 20 Mei $201 \overline{9}$

2. Jallo J, Vaccaro A. Autonomic dysreflexia. Dalam: Neurotrauma and Critical Care of the Spine. 2nd ed. New York: Thieme Medical Publishers, Incorporated; 2018.

3. Dryden D, Saunders L, Jacobs P, Schopflocher
D, Rowe B, May L, Yiannakoulias N, Svenson L and Voaklander D. Direct health care costs after traumatic spinal cord injury. The Journal of Trauma: Injury, Infection, and Critical Care.2005;59(2): 443-49.

4. Krassioukov A. Autonomic function following cervical spinal cord injury. Respiratory Physiology \& Neurobiology. 2009; 169(2): 157-64.

5. Cragg J, Noonan V, Krassioukov A, Borisoff J. Cardiovascular disease and spinal cord injury: Results from a national population health survey. Neurology. 2013; 81(8): $723-$ 28.

6. Lee E, Joo M. Prevalence of autonomic dysreflexia in patients with spinal cord injury above T6. BioMed Research International. 2017;2017:1-6.

7. Krum H, Brown D, Rowe P, Louis W, Howes L. Steady state plasma $[3 \mathrm{H}]$ —noradrenaline kinetics in quadriplegic chronic spinal cord injury patients. Journal of Autonomic Pharmacology. 1990;10(4):221-26.

8. Blackmer J. Rehabilitation medicine: autonomic dysreflexia. Canadian Medical Journal. 2003; 169 (9): 931-34.

9. Krassioukov A, Weaver L. Reflex and morphological changes in spinal preganglionic neurons after cord injury in rats. Clinical and Experimental Hypertension. 1995; 17(1-2): 361-73

10. Krenz N, Weaver L. Sprouting of primary afferent fibers after spinal cord transection in the rat. Neuroscience. 1998; 85(2): 443-58.

11. Krassioukov A, Weaver L. Morphological changes in sympathetic preganglionic neurons after spinal cord injury in rats. Neuroscience. 1996; 70(1): 211-25.

12. Eldahan K, Rabchevsky A. Autonomic dysreflexia after spinal cord injury: 
Systemic pathophysiology and methods of management. Autonomic Neuroscience. 2018;209:59-70.

13. Wan D, Krassioukov A. Life-threatening outcomes associated with autonomic dysreflexia: a clinical review. The Journal of Spinal Cord Medicine. 2013; 37(1): 2-10.
14. Petsas A, Drake J. Perioperative management for patients with a chronic spinal cord injury. BJA Education. 2015;15(3):123-30.

15. Lyford K, Borowczyk K, Danielleto S, Vlok R. Recognition and management of intraoperative autonomic dysreflexia. Journal of Surgery and Emergency Medicine. 2016; 1:e102:1-2 